\title{
Correlation in Seed Coat Colour and Pod Colour of French Bean Collected form Garhwal Himalayas
}

\author{
Navneeti Chamoli $^{1^{*}} \cdot$ Deepti Prabha ${ }^{1} \cdot$ Jai Singh Chauhan $^{1}$ \\ ${ }^{I}$ Department of Seed Science \& Technology, School of Agriculture and Allied Sciences, HNB Garhwal University, \\ Srinagar, Uttarakhand, India \\ *Corresponding author: navneetichamoli@gmail.com
}

Received: 25.11.2021; Revised: 18.12.2021; Accepted: 21.12.2021

(C) Society for Himalayan Action Research and Development

\begin{abstract}
Uttarakhand is one of the most important sources of French bean and the landraces grown throughout Uttarakhand are valuable sources of genes for breeding Programme and evolutionary studies. The objective of our experiment was to study about the correlation between pod colour and seed coat colour. Thirty accessions of French bean were collected from different districts of Garhwal region of Uttarakhand. Two years field trials (2019 and 2020) were conducted and the seed and pod data were recorded. Frequency distribution, UPGMA cluster analysis and Mantel correlogram revealed that the accession whose pod colour was green (without any pattern), their seeds were also plane while the accessions whose pods were carrying some pattern or stripes their pods were also textured or mottled. The knowledge of correlation between seeds and pods can be used in French bean breeding Programme. The knowledge could be used to identify within accession variability in French bean germplasm to protect each type from extinction
\end{abstract}

Keywords: French bean, accessions, UPGMA, correlogram, correlation.

\section{Introduction}

The French bean (Phaseolus vulgaris L.) is a nutritionally dense crop that is both economically and agriculturally important around the world (Fetahu et al., 2014). It is a crop with a wide range of morphological characteristics that is found all over the world (Gaitan et al., 2002). French bean has a small genome (580 Mbp/haploid genome) that is distributed across 22 chromosomes $(n=11)$ (Gepts et al., 2008). French be has a high nutritional value, with protein (22.24 to 31.59 percent), carbohydrates (27.80 to 34.78 percent), fibre (16.81 to 40.63 percent), ash (4.1 to 4.82 percent), and lipids (1.66 to 2.22 percent) (Fetahu et al.,2014). According to FAO, French bean global harvested area was 33.1 million ha and production was 28.9 million tons in 2019 . Asia shares $50 \%$ of the global production of common bean and Myanmar, India, Brazil, China, America were the top five dry bean producing countries in the world in 2000-2019 (WHO, 2020).Maharashtra, Uttarakhand, Jammu \& Kashmir, Uttar Pradesh and Himanchal Pradesh are the major states in India, where the French bean is growing in a large amount in an area of 137.54 thousand ha with production of 1370.21 thousand MT (NHB, 2015). A great diversity of French bean is present in Uttarakhand (Prabha et al., 2021) and 5776 ha area is under French bean production in Uttarakhand. Uttarkashi, Chakrata and Chamoli 
are main districts which are famous for the production of good quality French bean.

The seed coat, which is a major modulator of interactions between the internal structures of the seed and the external environment, not only maintains the integrity of the seed parts but also protects the embryo from mechanical injuries and pest disease attacks. The seed coat also improves seed survival in the soil, particularly in adverse environmental conditions, and aids in the prevention of species extinction in nature (Souza et al., 2010 and Tiryaki et al., 2014). At physiological maturity, the seed coat acquires its specific colour, and seed coat pigmentation has been shown to play an important role in seed dormancy and germination (Debeaujon et al., 2000, Powell et al., 1989, Ochuodho et al., 2008). Furthermore, pod and seed coat colour have been used to develop a simple method of improving seed quality for several crop species, including French bean (Possobom et al., 2015 and Hacisalihoglu et al., 2013, cowpea (Marwanto et al., 2013) rapeseed (Zhang et al.,2004), flax (Dana et al., 2008), and Arabidopsis (Debeaujon et al., 2000). Lots of variation in seed coat colour and pod colour is present in French bean. These variations can be used as morphological indicator to identify the French bean varieties during DUS testing. Therefore, this study was aim to determine seed coat colour variation and their possible correlation with pod colour parameters in French bean accessions collected from Garhwal Himalaya.

\section{Plant material}

The plant material used in this study comprised thirty accessions of French bean collected from different district of Garhwal region. Data on the germplasm were recorded during two vegetative cycles of $2019 \& 2020$ in the farmer's field at New Tehri, Tehri Garhwal. This field is located at $30.3739^{\circ} \mathrm{N}, 78.4325^{\circ} \mathrm{E}$ and elevation of $1750 \mathrm{~m}$ above sea level. The soil of the experimental farm is fine loam rich in organic matter. Average rainfall was recorded 1332.4 mm during April to November. The crop was sown in the month of April each year by following RBD in two replications. Ten seeds per row were sown for each accession with spacing of $30 \times 15 \mathrm{~cm}$. The harvesting was done in the month of November to December.

\section{Plant characters, Data recording \& Statistical analysis}

Two plant characters viz., pod colour and seed coat colour were recorded. Further, frequency distribution was observed by calculating their mean, UPGMA cluster analysis based on Euclidean distance and Mantel correlogram was observed by using PAST version 4.03. The Pearson correlation coefficient ( $\mathrm{R}$ and $p$ ) was calculated by using online calculator. 

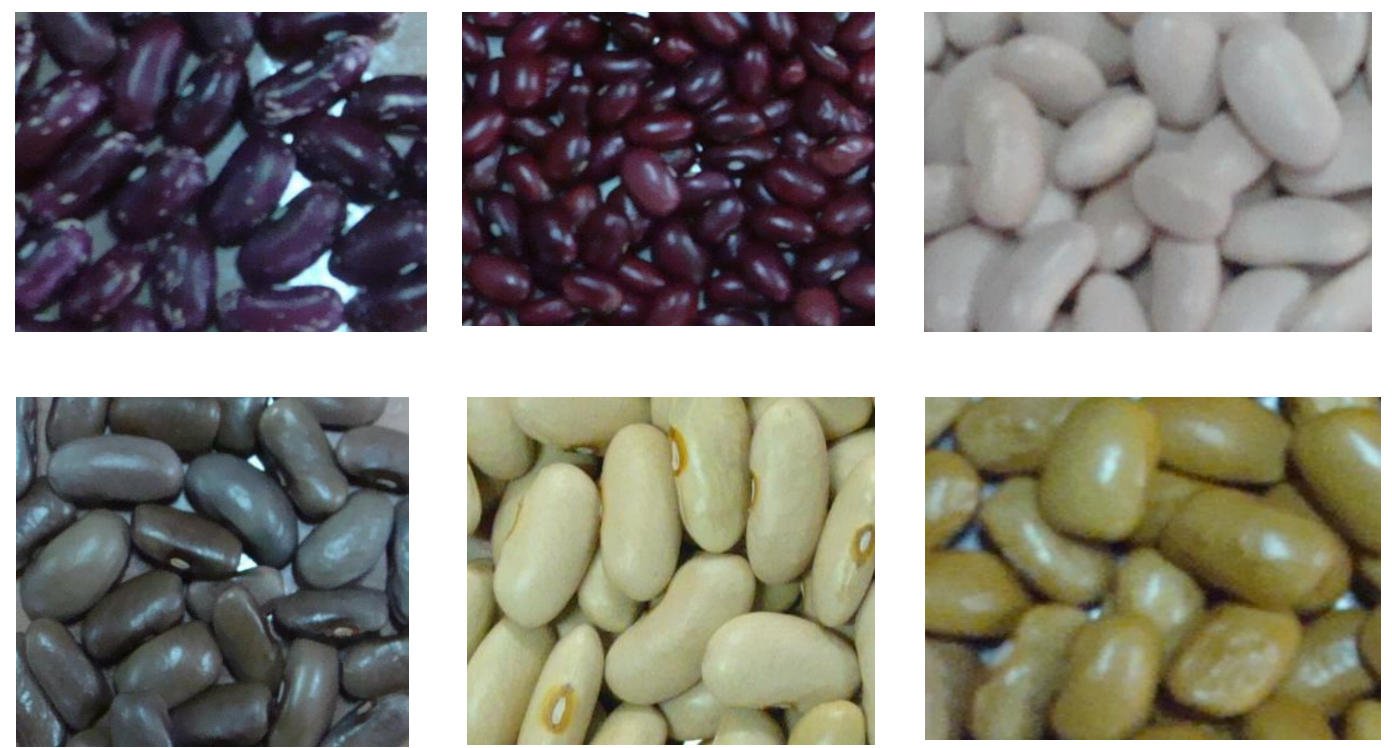

Plate-1. Seed accessions without texture in seed coat.

\section{Results and discussion}

\section{Frequency distribution}

The frequency distribution was recorded for both the traits and it was found that in the case of pod colour out of these twenty accessions, two accessions (GFB-06 and GFB-09) were maroon coloured (group-I), the accession GFB12 was white coloured (group-II), GFB-15 khaki coloured (group-III), GFB-19, GFB-20 yellow coloured (group-IV), GFB-01, GFB-02, GFB-03 and GFB-11 was cream mottled (group-V), GFB-04, GFB-05 and GFB-07 was maroon mottled (GFB-06), the colour of GFB-10 and GFB-13 was recorded dark blue mottled (group07), GFB-14 was khaki mottled (group-08), GFB-16 was light pink mottled (group-09), the colour of GFB-17 and GFB-18 was recorded as olive mottled (group-10) and GFB-08 was purple mottled (group-11).
The pod colour was found green for 17 accessions viz., GFB-03, GFB-04, GFB-05, GFB-06, GFB-07, GFB-08, GFB-09, GFB-10, GFB-12, GFB-13, GFB-14, GFB-15, GFB-16, GFB-17， GFB-18， GFB-19， GFB-20 one accession was found with black striped (GFB01 ), one with purple striped (GFB-11) and one with maroon striped (GFB-02). Arunga et al. (2015) found a correlation between flower colour and seed colour and they reported that white seeded accessions produced white flowers, black seeded accessions produce purple flower and brown seeded accessions produced purple or pink flowers. Similar pod and seed coat colour was also reported by Gopinath et al. (2013), Arunga et al. (2015), Nkhata et al.(2020), Sarikamis et al. (2009), Vaz et al. (2017), Caproni et al. (2019). 

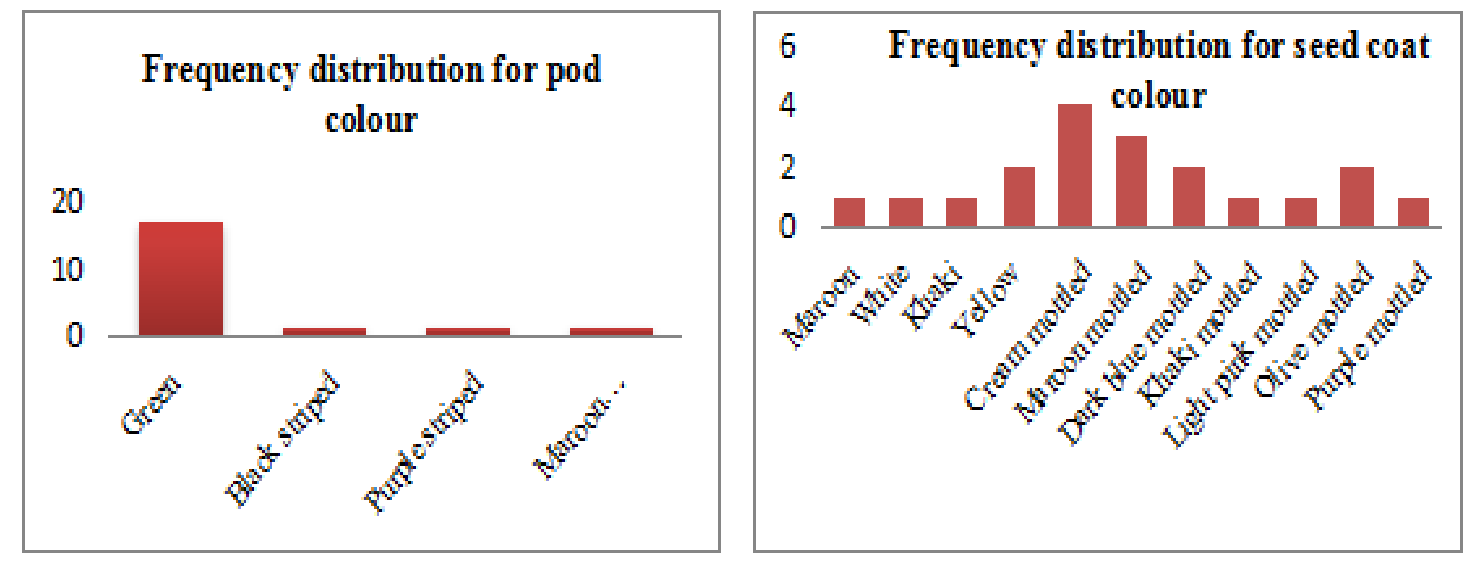

Fig.-1 (A) Frequency distribution for pod (B) Frequency distribution for seed coat colour

al.(2002). Verma et al. (2014) also reported

\section{Pearson Correlation Coefficient and Mantel correlogram}

0.4372R and 0.0157p value was recorded in our study, which showed a positive correlation between pod colour and seed coat colour. The mantel correlogram showed positive correlation, no correlation and a negative correlation. In the fig.-2, the red coloured group is showing a positive correlation, orange group is showing no correlation while yellow, cyan and blue coloured groups showing highly negative correlation. Karasu et al. (2010) found positive correlations between number of seeds per plant and number of seeds per pod, biomass yield and seed yield per plant. Similarly Sodagar et al. (2020) reported that Seeds/pod represented positive variable association with seed weight plant, pod length, pod width and pod length. Some other researchers Sehirali et al. (1980), Himan et al.(1996), Pooran-Chand et al.(1999), Amini et similar studies.

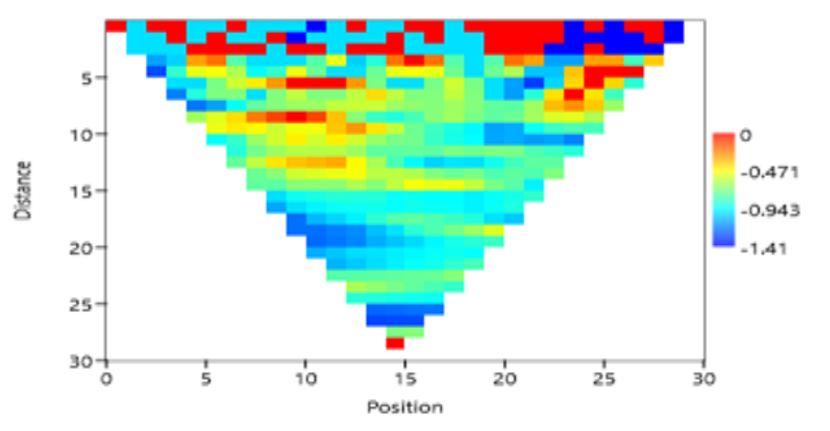

Fig-2. Correlation coefficient by Mantel correlogram.

Red coloured accessions are positively correlated while orange are showing no correlation. All other coloured groups are negatively correlated accessions. A correlation was recorded in our study between pod colour and seed coat colour and it was found that the seeds which were plane or single coloured, their pod colour were always green. No stripes were recorded in their pod. While the pod colour in which stripes of any colour was found were always mottled or speckled. 


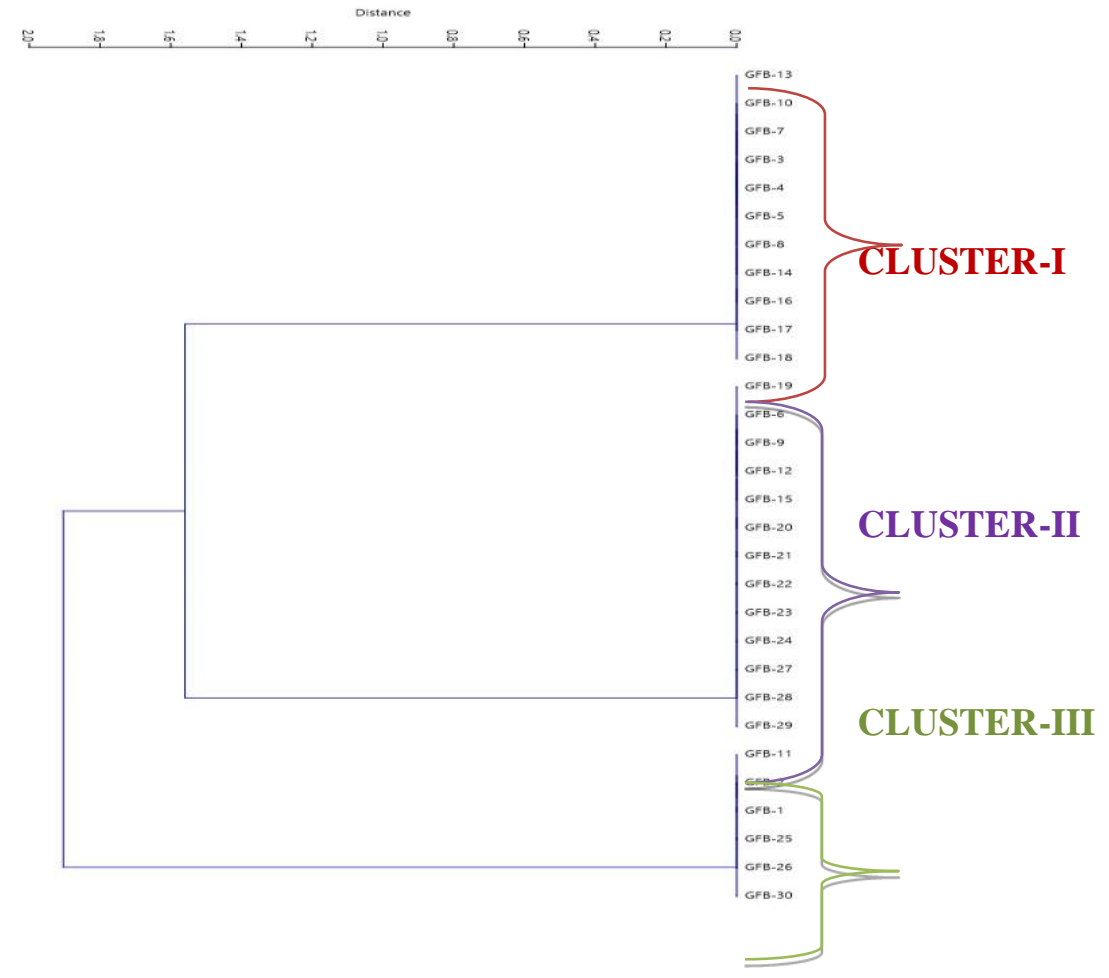

Fig-3. Mahalanobis cluster analysis of 30 french bean genotype on the basis of UPGMA euclidean distance.

*The I and III clusters are negatively correlated while the cluster II is positively correlated accessions

\section{Mahalanobis UPGMA Cluster analysis}

The Mahalanobis UPGMA Cluster analysis (Fig.3) clearly grouped all the highly correlated accessions in separate group. Two clusters were formed at the distance of 1.9, which were further

divided into three sub-clusters at the distance of 1.58. These clusters contain highly positive and egative correlated accessions. Cluster-I grouped eleven accessions viz.,GFB-13, GFB-10, GFB07, GFB-03, GFB-04, GFB-05, GFB-08, GFB14, GFB-16, GFB-17, GFB-18 cluster-II grouped a total of thirteen accessions viz., GFB-
19, GFB-06, GFB-09, GFB-12, GFB-15, GFB20, GFB-21, GFB-22, GFB-23, GFB-27, GFB28 , GFB-29 while the sub-cluster III contains six accessions viz., GFB-11, GFB-02, GFB-01, GFB-25, GFB-26 and GFB-30. In the cluster I and III all the accessions which are negatively correltaed with seed coat colour and pod colour are distributed. Here the negative correlation means pattern (speckeld and mottled) was absent in seed coat but absent in their pods. The II subcluster contained all the positively correlated accesions which means that seeds which were plane or no pattern were recorded and there pods were always plane or unpatterned. 
Conclusion: The structure and colour of the seed coat are important traits for legume species in determining the quality and commercial value of seeds. Seed coat colour is also a central target in several French bean species, and any trait correlated with it, particularly pod colour, is a convenient way to select/deselect desired/unwanted plant material in a breeding Programme. Defining such a correlation between coat colour and pod colour parameters of French bean may aid in the development of better forage crops in the common vetch breeding Programme. In the French bean used in the experiment, there is evidence of a link between pod colour and seed coat colour. Grain coat genetics knowledge can be very useful in French bean breeding because it is important in farmer and customer preference. The knowledge should be applied to identify within accession variability in French bean germplasm in order to protect each type from extinction.

\section{Acknowledgments}

We sincerely thank the all the villagers of Garhwal region who have been conserving the germplasm and provided us for the research purpose and for the filed which they provided us for trial in the pandemic situation. We also acknowledge the faculty of the Department of Seed Science and Technology for providing facilities to conduct the research.

\section{References}

Amini AM, Ghannadha and Mishani C (2002) Genetic diversity and correlation between different traits in common bean (Phaseolus vulgaris L.). Iranian Journal of Agricultural Science, 33 (4): 605-615

Arunga EE, Miriam K, Julius O, James $\mathrm{O}$ and Emy C (2015) Genetic diversity of determinate French beans grown in Kenya based on morpho-agronomic and simple sequence repeat variation. Journal of plant breeding and crop science, 7(8) : 240-250.

Caproni L, Raggi L, Ceccarelli S, Negri V, and Carboni A (2019) In-Depth Characterisation of Common Bean Diversity Discloses Its Breeding Potential for Sustainable Agriculture. Sustainability, 11:5443.

Dana W and Ivo w, (2008) Computer image analysis of seed shape and seed color for flax cultivar description. Computers and Electronics in Agriculture, 61(2):126$135,2008$.

Debeaujon K M, Léon $\mathrm{K}$ and Koornneef $\mathrm{M}$ (2000) Influence of the testa on seed dormancy, germination, and longevity in Arabidopsis. Plant Physiology, 122(2):403-413.

Dhiman KR (1996). Path analysis in dry bean germplasm. Indian Journal of Genetic and Plant Breeding, 56 (4): 439-446. 
Fetahu Sh, Kaciu S, Aliu S, Bajraktari I, Zeka D, Rusinovci I, Salihu S, Haxholli I, Sylanaj S, Shala A and A. Beluli (2014) Genetic and phenotypic diversity among some common bean landraces (Phaseulus vulgarisL.) in Kosovo. Proc. Vth Balkan Symp. on Vegetables and Potatoes. Acta Hort. 960, pp 169-74.

Gaitan E, Duque MC, Edwards K, Tohme J (2002) Microsatellite repeats in common bean (Phaseolus vulgaris L.): isolation, characterization, and cross-species amplification in Phaseolus spp. Crop Sci 42:2128-2136.

Gepts P and Aragao F (2008) Genomics of Phaseolus beans, a major source of dietary protein and micronutrients in the tropics. Genomics of Tropical Crop Plants. Springer, 113-143.

Gopinath SM, Anushree V K, Dayananda KS, Ismail S, Drishya M, Nair V (2013) Assessment of Genetic Diversity of French Bean Using SSR Primers. International Journal of Innovative Research in Science. Engineering and Technology, 2(9):2319-8753

Hacisalihoglu G and Settles AM (2013) Natural variation in seed composition of 91 common bean genotypes and their possible association with seed coat color. Journal of Plant Nutrition, 36(5):772-780.
Karasu A And Oz M (2010) A Study On Coefficient Analysis And Association Between Agronomical Characters In Dry Bean (Phaseolus Vulgaris L.). Bulgarian Journal Of Agricultural Science. 16:203-211.

Marwanto M (2004) Soybean seed coat characteristics and its quality losses during incubator aging and storage. Jurnal Ilmu-Ilmu Pertanian Indonesia, vol. 6, pp. 57-65, 2004.

National Horticulture Board report 2015.

Nkhata W, Shimelis H, Melis R, Chirwa R, Mzengeza T and Mathew I (2020) Population structure and genetic diversity analyses of common bean germplasm collections of East and Southern Africa using morphological traits and high-density SNP markers. PLoS ONE 15(12):e0243238.

Ochuodho JO and Modi AT (2008) Dormancy of wild mustard (Sisymbrium capense) seeds is related to seed coat colour. Seed Science and Technology, 36(1):46-55, 2008.

Pooran-Chand (1999). Character association and path analysis in rajmash. Madras Agricultural Journal, 85: 188-190. Possobom MTDF, Ribeiro ND, Zemolin AEM, and Arns FD (2015) Genetic control of the seed coat colour of Middle 
American and Andean bean seeds.

Genetica, 143(1):45-54, 2015.

Powell AA (1989). The importance of genetically determined seed coat characteristics to seed quality in grain legumes," Annals of Botany, 63(1):169175, 1989.

Prabha D, Chamoli N, Negi YK and Chauhan JS (2020). Newly Identified Anthracnose Resistant French Bean (Phaseolus vulgaris) Accessions from Garhwal Hills of Uttarakhand, India. Int.J.Curr.Microbiol.App.Sci, $\quad$ 9(2): $2748-2751$

Sarikamis G, Yasar F, Bakir M, Kazan K and Ergul A (2009) Genetic characterization of green bean (Phaseolus vulgaris) genotypes from eastern Turkey. Genet. Mol. Res. 8 (3): 880-887.

Sehirali S (1980) Effect of plant density on some characters relation in dwarf bean (Phaseolus vulgaris L.) Journal of Agriculture Faculty 29 : 738.

Sodagar A, Ahsan M, Iqbal SU, Siddiqui SA (2020) Correlation coefficient and path coefficient analysis for yield and its component traits in common bean (Phaseolus vulgaris L.) germplasm International Journal of Scientific and Engineering Research 11(12):1081-1086
Souza TLPO, Dessaune SN, Sanglard DA, Moreira MA and Barros EG (2011) Characterization of the rust resistance gene present in the common bean cultivar Ouro Negro, the main rust resistance source used in Brazil. Plant Pathol. 60:839-845.

Tiryaki I and Tope M (2014) A novel method to overcome coat-imposed seed dormancy in Lupinus albus L. and Trifolium pratense L. Journal of Botany, 6: 647469.

Vaz DC, Junior OPM and Peixoto N (2017) Agro-morphological characterization and genetic divergence assessment in bush snap bean genotypes. Agropec. Trop. Goiania, 47(2):134-144,

Verma V , Jha Ak, Pandey A, Kumar A, Choudhury $P$ And Swer $T$ (2014)Genetic divergence, path coefficient and cluster analysis of French bean (Phaseolus vulgaris) genotypes. Indian Journal of Agricultural Sciences 84 (8): 925-30M.

World Health Organization report 2020.

Zhang XK, Chen J, Chen HZ, Wang and Li JL (2008) Imbibition behavior and flooding tolerance of rapeseed seed (Brassica napus L.) with different testa color. Genetic Resources and Crop Evolution, vol. 55, no. 8, pp. 1175-1184. 